\title{
Floral and reproductive biology of Matisia cordata (fam: Malvaceae)
}

\author{
Mariluz Aguilar Castro ${ }^{1}$, Daily Gómez Ramírez², Verónica Álvarez Osorio³, Sandra Muriel Ruiz
}

\begin{abstract}
In Colombia there is a large diversity of promising fruit trees, one of them is Matisia cordata. Sapoti species is appreciated by the consumers, although it is produced in small volumes by traditional productors. The objective of this research is to describe the floral and reproductive biology of sapoti, including floral visitors that act as biotic pollination agents. The study was conducted in two farms, between February/2016 and July/2017. In the first farm, floral buds were marked to follow the stages until fruit formation, pollination mechanism was studied, and floral visitors were collected for identification. In the second farm, flowers were marked to measure the floral nectar production. The duration from floral bud to ripe fruit was 269 days, the $2.7 \%$ of the flowers reached the fruit stage. Twenty-five floral visitors were registered, seven of which contacted the sexual whorls, specially Meliponini bees, hummingbirds and bats from Artibeus and Glossophaga genus. M. cordata is a prevalently allogamous species, it attracts diurnal and nocturnal animals, which can contribute to the pollination process. The flowers produced $1.6 \mathrm{ml}$ of nectar with a sugar content from 6.2 to $11^{\circ}$ Brix. The sapoti flowers constitute an abundant and valuable resource for animals from the region.
\end{abstract}

Index terms: nectar; pollination; phenology; promissory fruit; sapoti.

\section{Biologia floral e reprodutiva da Matisia cordata (fam: Malvaceae)}

Corresponding author: sbmuriel@elpoli.edu.co

\section{Received: August 04, 20}

Accepted: February 22,2021

Copyright: All the contents of this journal, except where otherwise noted, is licensed under a Creative Commons Attribution License.
Resumo -Há uma grande diversidade de árvores promissórias na Colômbia, uma das quais é Matisia cordata (sapoti). O sapoti é uma espécie muito bem recebida pelos consumidores, mesmo que seja produzida em pequenos volumes pelos produtores tradicionais. O objetivo desta investigação é descrever a biologia floral e reprodutiva do sapoti, incluindo visitantes florais que atuam como agentes bióticos de polinização. O estudo foi feito no período de fevereiro/2016 julho/2017. Na primeira fazenda, os botões florais foram marcados para acompanhar os estágios até à formação dos frutos, o mecanismo de polinização foi estudado e os visitantes florais foram coletados para identificação. Na segunda, as flores foram marcadas para medir a produção de néctar floral. A duração desde o broto floral até ao fruto maduro foi de 269 dias. Vinte e cinco visitantes florais foram registrados, sete dos quais tiveram contato com as espirais sexuais, especialmente abelhas Meliponini, beija-flores e morcegos dos gêneros Artibeus e Glossophaga. M. cordata e, principalmente, uma espécie alógama, que atrai diferentes animais diurnos e noturnos que podem participar do processo de polinização. As flores produziram 1,6 $\mathrm{mL}$ de néctar com um teor de açúcar entre $6,2 \mathrm{e} 11^{\circ}$ Brix. As flores de sapoti constituem um recurso abundante e valioso para os animais da região de estudo.

Termos para indexação: néctar; polinização; fenologia; fruta promissora; sapoti.

\footnotetext{
${ }^{1}$ Agronomist, Facultad de Ciencias Agrarias, Politécnico Colombiano Jaime Isaza Cadavid, Medellín - Colombia. E-mail: mariluzaguilarcas@ gmail.com (ORCID: 0000-0003-1686-7285)

${ }^{2}$ Agronomist, Facultad de Ciencias Agrarias, Politécnico Colombiano Jaime Isaza Cadavid, Medellín - Colombia. E-mail: daily_gomez16122@ elpoli.edu.co(ORCID: 0000-0003-3945-6331)

${ }^{3}$ Agronomist, Facultad de Ciencias Agrarias, Politécnico Colombiano Jaime Isaza Cadavid, Medellín - Colombia. E-mail: veronicaalvarez@ elpoli.edu.co(ORCID: 0000-0002-9950-1301)

${ }^{4}$ Agronomist, Facultad de Ciencias Agrarias, Politécnico Colombiano Jaime Isaza Cadavid, Medellín - Colombia. E-mail: sbmuriel@elpoli. edu.co (ORCID: 0000-0002-1938-0096)
} 


\section{Introduction}

There are nearly 400 edible native species in Colombia, most of them fruits, known as promissory species (NATES et al., 2017). Sapoti (Matisia cordata Bonpl.) is one of them, it belongs to the Bombacoidea subfamily (Fam: Malvaceae) (TROPICOS, 2018), native from the Amazon (MORTON, 1987), and distributed along Brazil, Peru, Ecuador, Venezuela and Colombia (ROGG, 2001). In some regions of Colombia, sapoti is cropped in small patches as part of traditional orchards or dispersed near the houses (ÁLVAREZ et al., 2015). Sopetrán municipality has the $57.4 \%$ of the total sapoti planted area of northwest Colombia (Secretaría de Agricultura y Desarrollo Rural- Antioquia, 2014) where traditional productors sell the fruit at local and national markets. Tropical fruits are widely accepted in the international market as exotic fruits that may contribute to the nutritional balance in the diet of consumers (STRIEGEL et al., 2019).

This species can be $30 \mathrm{~m}$ tall when cropped and $40 \mathrm{~m}$ tall when found within the forest (MORTON, 1987; LIM, 2012). It has cauliflower, yellow, short pedicelled and hermaphrodite flowers arranged from three to nine fascicles (JANSON et al., 1981; CHÍZMAR, 2009). The fruit is globose or ovoid, with a strong, powdery, greenish brown peduncle. It has a persistent nipple-shaped calyx and contains up to five wedge-shaped seeds (LIM, 2012). The pulp of a mature fruit is deep orange colored, juicy, fibrous and aromatic (CERÓN et al., 2014). In its natural habitat, fruits and seeds are dispersed by vertebrates, especially primates (ALVAREZ and TERBORGH, 2011), and bats (CHÍZMAR, 2009).

Flowering of $M$. cordata lasts from three to four months once a year. In Costa Rica, flowering takes place between January and March, with a maximum number of flowers during February (according to the author, one tree exhibiting 10.000 flowers with a nectar production of 10 L approx.) (TSCHAPKA, 2004). In Panama, sapoti flowering occurs during dry season between December and March; fructification begins at rainy season from April to June with fruits reaching its total maturity in August (CHÍZMAR, 2009). In non-flooded regions at the Peruvian amazon, sapoti flowering is maximum in August, at dry season when trees lose leaves and flowers can be seen from great distances (JANSON et al., 1981). According to the authors, these flowers are rich in nectar and easily accessible by mammals (JANSON et al., 1981). However, there are no detailed studies on the species reproductive phenology.

Sapoti flowers are frequently visited by biotic agents such as hummingbirds, bees and wasps (CHÍZMAR, 2009). Although there are no studies of sapoti pollinators in Colombia, some pollinators have been registered in other countries. In Costa Rica, the Glossophaga commissarisi,
Hylonycteris underwoodi, Lichonycteris obscura and Lonchophylla robusta bats were seen nectar feeding and carrying sapoti pollen grains, with Lonchophylla robusta showing preference for sapoti flowers (TSCHAPKA, 2004); in the Peruvian amazon, M. Cordata flowers were visited by five mammal species and four different genera of marsupials (JANSON et al., 1981). Nevertheless, these studies have to be carefully read since not all floral visitors are pollinators since they look for flower resources for their hatchlings, but do not necessarily contribute to pollination (ALVES-DOS-SANTOS et al., 2016). Some visitors even cause flower damage piercing buttons, corollas or anthers (ROJAS, 2013; GUTIÉRREZ et al., 2018). As for pollinators, they legitimately visit the reproductive whorls, that is, they carry pollen and touch the stigma of flowers of the same species (ALVES-DOS-SANTOS et al., 2016). Therefore, it is important to carry out detailed studies about floral and reproductive biology of promissory species. These studies would help traditional productors to properly manage their crops.

The aims of this study are to describe the flowering and fruiting stages of sapoti, its pollination mechanism, and to register floral visitors and its pollen loads in the tropical dry forest of nearby western Antioquia. The results of this study will assist crop planning and future pollinator effectiveness studies. These latter studies are relevant since the number of traditional farms (with agroforestry systems that include sapoti trees) is decreasing and the change in the land use might affect the network of organisms that interact with sapoti.

\section{Materials and Methods}

The study was carried out between February/2016 and July/2017 in two farms located on the tropical dry forest of Antioquia (Colombia). This ecosystem is characterized by vegetation adapted to long periods of drought (PIZANO and GARCIA, 2014). The first farm, named El Clavel (coordinates $6^{\circ} 30^{\prime} \mathrm{N}$ and $75^{\circ} 45^{\prime}$ W), has 100 sapoti trees distributed in an agroforestry arrangement with other species such as: citrus, arazá (Eugenia stipitata), cacao (Theobroma cacao), casava (Manihot esculenta), guava (Psidium guajava) and banana (Mussa spp.) (BARRERA, personal comunication). In the second farm, named Los Ruices (coordinates $6^{\circ} 44^{\prime}$ $\mathrm{N}$ and $75^{\circ} 44^{\prime} \mathrm{W}$ ), the flowers nectar study was carried out since at least $50 \%$ of the trees were flowering. Plantations are 25 and 20 years old in El Clavel and Los Ruices farms, respectively; the crop management main activity is watering and harvesting weekly; insecticides and fungicides are not applied.

Pollen viability, stigma receptivity and pollination mechanism. In order to recognize the pollen obtained from the floral visitors, an initial description of the pollen grain 
was made from 30 flower buds before anthesis. Buds were randomly chosen from El Clavel farm trees, they were storage in Eppendorf tubes with alcohol and analyzed in the Paleoecology Laboratory of the Universidad Nacional de Colombia-Medellín. An acetolysis process according to the modified Erdtman method (1996) was carried out to isolate the pollen and eliminate its protoplasmic content. The permanent plates were arranged and codified according to FONNEGRA (1989). The obtained pollen was added to a pollen laboratory reference collection. The pollen description was carried out with the arithmetic average value of 20 measures of the following parameters: $\mathrm{P}$ (Polar axis in equatorial view), E (Equatorial axis in equatorial view), DE (Equatorial Diameter in equatorial view), LA (Apocolpio side) and exine, sexin and nexin thickness. Photographs and measures were taken in a Zeiss light microscope (Primo star) with $100 \mathrm{X}$ and $40 \mathrm{X}$, using the Axioncam ERc 5s camera program.
In order to determine pollen viability and stigma receptivity, 66 flowers were collected: 22 1-day flowers, 22 2-days flowers and 22 3-days flowers (Figure 1a-c). Viability was evaluated using two methods: tetrazolium test and in vitro germination test (SHIVANNA and TANDON, 2014). In the first method, pollen grains were immersed in 2,3,5-triphenyltetrazolium chloride $(0.5 \%)$ solution and incubated at lab temperature for 60 minutes; 112 pollen grains per flower were observed, considering viable those that have turned red. In the second test, a culture medium was prepared in previously sterilized Petri boxes with sucrose (16\%) and agar $(0.4 \%)$. Pollen was taken directly from the flowers; 24 hours later, 120 pollen gains were observed under the microscope (40x) to determine the percentage of germinated pollen per flower age. Sapoti flowers stigma receptivity was assessed in field following standard procedures detailed in OSBORN (1988) and SHIVANA and TANDON (2014): 1-day, 2-day and 3-day flowers were collected, a drop of $40 \%$ hydrogen peroxide was put on the stigma and the production of bubbles was registered as an indicative of receptivity. The oxygen liberation through the stigma surface rate was classified as non-receptive (no oxygen liberation), poorly receptive (average oxygen liberation) and highly receptive (abundant oxygen liberation) (SHIVANNA and TANDON, 2014). Test results were analyzed with the chisquare statistic, in STANGROOM (2021).

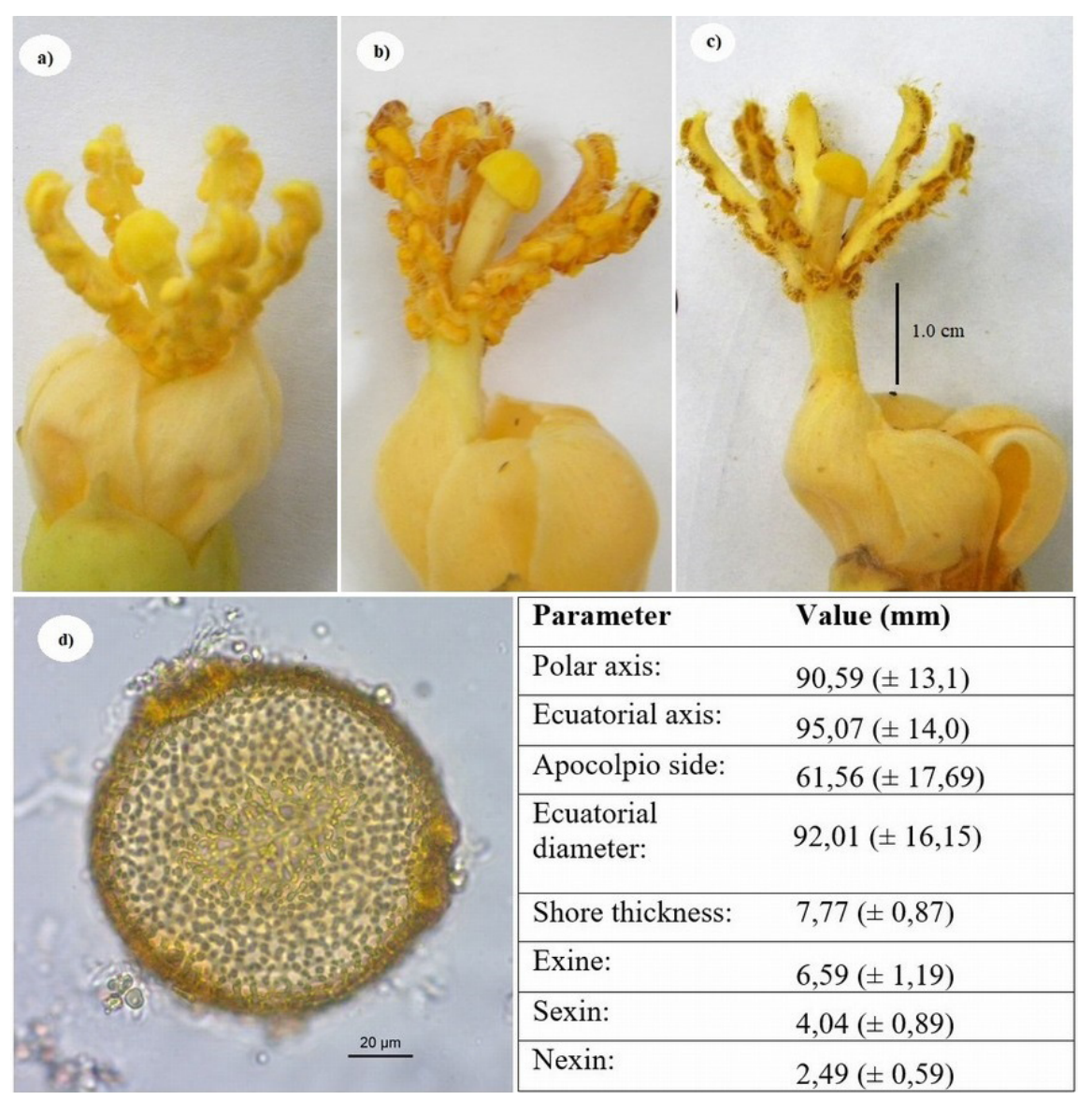

Figure 1. Classification of Matisia cordata flowers according to its age and pollen grain description (The Clavel farm, Sopetrán, Antioquia - Colombia). 
Two processes were performed to evaluate the pollination mechanisms. In the first one, 20 flowers were emasculated in day 1 of anthesis and were enclosed in a plastic glass wrapped in cloth; they were manually pollinated in day 3 using flower pollen from other trees (crossed or self-pollination), which was collected in a Petri box and applied with a paintbrush. In the second process, 20 flower buds were enclosed before anthesis, each bud in a plastic glass wrapped in cloth to guarantee the arrival of the flower pollen to its own stigma (autopollination). These processes were compared with a control treatment (natural pollination), in which 150 flower buds were marked and tracked until fruit formation.

Nectar quantification. 30 flowers were collected from full flowering trees, flowers were marked according to their anthesis as explained below: 10 1-day flowers, 10 2-days flowers and 10 3-days flowers. Nectar was extracted between 10:00h and 12:00h and then again from $14: 00 \mathrm{~h}$ to $16: 30 \mathrm{~h}$, according to the observed visiting hours of the diurnal floral visitors. The same extraction was made two days in a row. Nectar extraction and its measure was performed with a $2 \mathrm{ml}$ micropipette, then it was poured in Eppendorf tubes and analyzed with a hand Vee Gee Scientific Btx-1 refractometer to determine the total sugar content. Effects of sampling hours and flower age on the nectar volume and its content of total soluble solids (SST) was evaluated. This evaluation was achieved through a variance analysis and a Tukey mean test using RStudio software (R Development Core Team. 2009).

Floral visitors. The registration of floral visitors was made with emphasis on day visitors of the Insecta Order and birds, and on night visitors of the Chiroptera Order. Insects observed in the sapoti flowers were manually collected with an entomology net every seven days; additionally, Van Somerer-Rydon traps with eucalyptol and methyl salicylate attractants were placed twice, from 9:00h to 16:00h. All insects were identified in the Francisco Luis Gallego Entomology Museum of the Universidad Nacional de Colombia - Medellin. Individuals of each species were taken to the Palynology Laboratory in order to determine their pollen loads. First, every insect was washed with commercial ethyl alcohol at $99 \%$, the residue was passed through a $150 \mu \mathrm{m}$ mesh sieve and put in $15 \mathrm{ml}$ Falcon tubes. The tubes were centrifugated three minutes, then the supernatant was removed using a Pasteur pipette. The precipitated pollen was put in Eppendorf tubes with three glycerin drops and taken to a $45^{\circ} \mathrm{C}$ oven for $70 \mathrm{~min}$. A permanent arrangement of two plates per species with two subsamples per plate was settled following the KISSER (1935) protocol. As for the visiting birds, a photographic register was carried out for its identification.

For Chiroptera identification, two capture events inside the agroforest system were performed from 18:00h to $23: 30 \mathrm{~h}$, during the flowering stage of sapoti. Mist nets of
6 and $12 \mathrm{~m}$ were installed in the crop streets. Each trapped bat was put in a cloth bag to determine its species and was subsequently released. Identification was carried out by members of the Mastozoology group of the University of Antioquia. In order to reduce pollen loss caused by manipulation, samples of pollen loads in bats were taken when removing the animals from the mist net. Each bat was cleaned with a glycerinated gelatin and the pollen sample was put in Eppendorf tubes. If the bat had feces, a sample was also taken and storage in a different tube. Fractions of glycerinated gelatin with pollen were treated with and without fuchsin, and subsequently assembled in plates following the KISSER (1935) protocol. As for the faecal samples, the modified Potash $(\mathrm{KOH})$ procedure was used (PRAGLOWSKI, 1970). All samples were analyzed under a Zeizz ${ }^{\circledR}$ Primo Star microscope, in 10X and 40X magnifications. Microphotographs were taken with an Axiocam ERc $5 \mathrm{~s} \AA\left(\right.$ Zeizz $\left.{ }^{\circledR}\right)$ camera. Pollen identification and description was done by comparing the collected samples with previous identified pollen of sapoti flowers.

Flowering and fruits. The BBCH scale was used for phenological stages identification (ENZ and DACHLER, 1998). The scale was adjusted for the species and used to describe the developmental phases of flowers (stage 5), flowering (stage 6), fruit development (stage 7) and fruit maturity (stage 8). The tracing of 150 flower buds until the matured fruit stage or flower bud abortion was carried out in 30 buds/tree in five random trees. Stages of bud, flower, anthesis and fruit formation were determined. All structures were measured with a manual Vernier caliper and photographs were taken with a Nikon Coolpix L100 camera.

\section{Results and Discussion}

Pollen viability, stigma receptivity and pollination mechanism. M. cordata pollen is yellowish, oblatespheroidal shaped, with radial symmetry, isopolar polarity, three pores with the presence of coast, reticulated sculpture and the presence of cracks in the ceiling. Pollen measures are indicated in Figure 1d.

In the pollen viability test, the tetrazolium test showed that 1-day and 2-days old flowers had more viable pollen than the 3 -days old flowers (Figure $2 a)(X 2=44.9$, $\mathrm{P}<0.00001$ ) (Figure 2b); the pollen tube germination test showed lower germination in 3-days old flowers (X2 = 41.5, $\mathrm{P}<0.00001$ ) (Figure 2b). On the contrary, 3-days old flowers had more receptive stigmas $(\mathrm{X} 2=35.3, \mathrm{P}<$ 0.00001 ) (Figure 2c). These results suggest that after the anthesis, the pollen is viable but the stigma is not receptive; in the third day, pollen is losing viability but the stigma is completely receptive. 

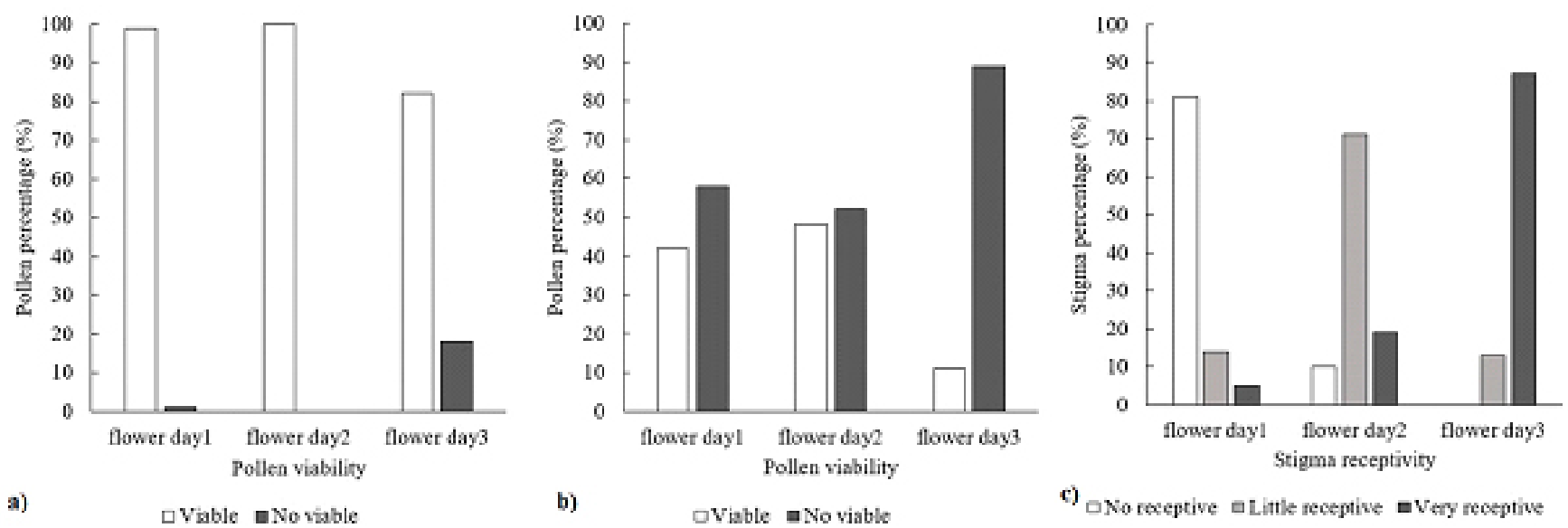

Figure 2. Pollen grain vaibility and stigma receptivity of Matisia cordata flowers.

Natural pollination (not controlled pollination) was about $20 \%$; self-pollination was about $10 \%$ and crossed pollination (emasculated flowers) was about $3.3 \%$. These results must be carefully analyzed because emasculation was a stressful effect for flowers since cutting the stamens caused wilt in most of them. Hence technique must be improved.

Floral Visitors. Twenty-five floral visitors were registered: 13 insects, 8 chiropterans and 4 birds (Figure $3)$. Eleven of the observed insects were Hymenoptera and two were Diptera (Table 1). Insects found upon sexual whorls were Trigona (frieseomelitta) nigra and $T$. fulviventris, both found with high pollen loads (Table 1) (Figure 3); Tetragonisca angustula and Nannotrigona sp. were also found on the whorls but their pollen load could not be measured. Exaerete smaragdina, and Euglossa sp. were captured in flight at the sapoti crops. Although pollen was found upon these two species, it was less than the amount of pollen found in T. nigra and T. fulviventris. The Polistes canadensis, Synoeca sp., Polybia sp. and Zethus sp. are predatory wasps (JEANNE and TAYLOR, 2009), they were found upon non-sexual whorls hunting insects among the sapoti flowers. In foraging activity, these wasps can collect water, carbohydrates, preys and construction material for their nets (RAVERET-RICHTER, 2000). An individual from the Formicidae family was observed nectar-robbing, but none of the three Diptera order morphospecies had contact pollen.

As for the birds (Table 1), Amazilia tzalcatl was the only nectariferous bird. It was observed in contact with the sexual whorls while the other species were hunting insects among the sapoti flowers. Among the eight Chiroptera species (Table 1), Aribeus literatus was the most captured and all individuals had sapoti pollen. Pollen content was found in body and faeces of Aribeus literatus and Glossophaga sorcina, thus there is certainty of its consumption (Table 1). The latter also happened with Sturnira sp. Pollen was also fund in Phyllostomus discolor and Dermanura sp.
Nectar quantification. Sapoti flowers produced 1.6 $\mathrm{ml}$ of nectar for three days, total sugar content varying between 6.2 and $11 \%$ of ${ }^{\circ}$ Brix. Because of the nectar abundance in the flowers, nectar spilled upon the leaves creating an attractive environment for many animals. Nectar production was similar among flowers of different ages $(\mathrm{F}=1.36, P=0.27)$, with a greater total sugar concentration in 2-days flowers $(\mathrm{F}=10.85, P=0.002)$. Only $20 \%$ of the flowers reached the third day, showing some wilt symptoms.

Volume of the extracted nectar and total sugar concentration were affected by the sampling hour: a greater nectar volume $(\mathrm{F}=5.13, P=0.03)$ was obtained on morning hours, while greater sugar percentage $(\mathrm{F}=$ $15.32, P=0.00$ ) was found during afternoon hours.

Flower and Fruit Formation. Total duration of flowering and fructification was 269 days, average. Only four of the 150 floral buds initially marked reached the matured fruit stage, that is the $2.7 \%$. Changes from floral buttons to matured fruit are presented in Figure 4. The flowering stage of sapoti trees from the study region began in November with formation of flower buds (stage 5, according to ENZ and DACHLER, 1998) (Figure 4a) and ended in July with fruit ripening (stage 8 ). The ending of flowering (stage 6) coincided with the dry season that usually occurs between December and February. Nevertheless, trees did not lose leaves as registered in the Peruvian Amazon by JANSON et al., (1981). This could be explained by the manual watering that was done weekly by farmers. This activity prevents the trees to go under hydric stress. Starting in February, all plants were in the fruit development (stage 7) (Figure $4 \mathrm{c}$-d); harvesting of matured fruits was carried out between July and October (Figure 4 e-f). Duration of each state was: flower buds 15 \pm 5 days, flower between 3 and 5 days, and fruit filling until harvesting maturity 200 days. If flowers were not pollinated in the first three days, they fell on the $5^{\text {th }}$ day. If fecundation was possible, ovary transformation began, and the last petals fell after 12 days. 
Table 1. Matisia cordata floral visitors and pollen loads from the agroforest systems (Sopetrán, Antioquia - Colombia).

\begin{tabular}{|c|c|c|c|c|}
\hline Order & Famiy & Morphospecie & $\begin{array}{l}\text { Average pollen grains obtained } \\
\text { from the individual }\end{array}$ & \\
\hline Diptera & Sepsidae & Sepsidae & N/A & \\
\hline Diptera & Syrphidae & Ornidia obesa (Fabricius, 1775) & 0 & \\
\hline Hymenoptera & Apidae & Euglossa sp. & $3,5( \pm 1)$ & \\
\hline Hymenoptera & Apidae & \begin{tabular}{|l} 
Exaerete smaragdina \\
(Guérin- Méneville, 1845)
\end{tabular} & $12( \pm 7)$ & \\
\hline Hymenoptera & Apidae & $\begin{array}{l}\text { Nannotrigona sp. (Cockerell, } \\
1922)\end{array}$ & $\mathrm{N} / \mathrm{A}$ & \\
\hline Hymenoptera & Apidae & $\begin{array}{l}\text { Tetragonisca angustula } \\
\text { (Illiger, 1806) }\end{array}$ & $\mathrm{N} / \mathrm{A}$ & \\
\hline Hymenoptera & Apidae & $\begin{array}{l}\text { Trigona (frieseomelitta) nigra } \\
\text { (Provancher, 1888) }\end{array}$ & $1203( \pm 1994)$ & \\
\hline Hymenoptera & Apidae & Trigona amalthea (Olivier, 1789) & N/A & \\
\hline Hymenoptera & Apidae & $\begin{array}{l}\text { Trigona fulviventris } \\
\text { (Guérin-Méneville, 1845) }\end{array}$ & $41( \pm 16)$ & \\
\hline Hymenoptera & Formicidae & Camponotus sp. (Mayr, 1861) (s.f) & 0 & \\
\hline Hymenoptera & Vespidae & Polistes canadensis (Linneo, 1758) & 13 & \\
\hline Hymenoptera & Vespidae & Polybia sp. (Fabricius, 1804) & 4 & \\
\hline Hymenoptera & Vespidae & Synoeca sp. (Linnaeus 1767) & 0 & \\
\hline Hymenoptera & Vespidae & Zethus sp. (Fabricius, 1804) & 0 & \\
\hline Trochiforme & \multicolumn{2}{|l|}{ Trochilidae } & Amazilia tzacatl (De la Llave, 1833) & $\mathrm{N} / \mathrm{A}$ \\
\hline Cuculiforme & \multicolumn{2}{|l|}{ Cuculidae } & Crotophaga sp. (Linnaeus, 1758) & $\mathrm{N} / \mathrm{A}$ \\
\hline Passeriforme & \multicolumn{2}{|l|}{ Turdidae } & Turdus ignobilis (P.L.Sclater, 1858) & $\mathrm{N} / \mathrm{A}$ \\
\hline Passeriforme & \multicolumn{2}{|l|}{ Tringillidae } & $\begin{array}{l}\text { Euphonia laniirostris (d'Orbigny } \\
\text { and Lafresnaye, 1837) }\end{array}$ & N/A \\
\hline Chiroptera & \multicolumn{2}{|c|}{ Phyllostomidae } & Artibeus lituratus (Olfers, 1818) & $364( \pm 651)$ \\
\hline Chiroptera & \multicolumn{2}{|c|}{ Phyllostomidae } & Carollia castanea (H.Allen, 1890) & 9 \\
\hline Chiroptera & \multicolumn{2}{|c|}{ Phyllostomidae } & Sturnira sp. (Gray, 1844) & $112( \pm 135)$ \\
\hline Chiroptera & \multicolumn{2}{|c|}{ Phyllostomidae } & Sturnira lilium (E.Geoffroy, 1810) & 224 \\
\hline Chiroptera & \multicolumn{2}{|c|}{ Phyllostomidae } & Sturnira ludovici (Anthony, 1924) & 0 \\
\hline Chiroptera & \multicolumn{2}{|c|}{ Phyllostomidae } & Dermanura sp. (Gervais, 1856) & 0 \\
\hline Chiroptera & \multicolumn{2}{|c|}{ Phyllostomidae } & Glossophaga sorcina (Pallas, 1766) & $408( \pm 224)$ \\
\hline Chiroptera & \multicolumn{2}{|c|}{ Phyllostomidae } & $\begin{array}{l}\text { Phyllostomus discolor (Wagner, } \\
1843 \text { ) }\end{array}$ & 308 \\
\hline
\end{tabular}

N/A: not applied since individual was observed but not captured. 


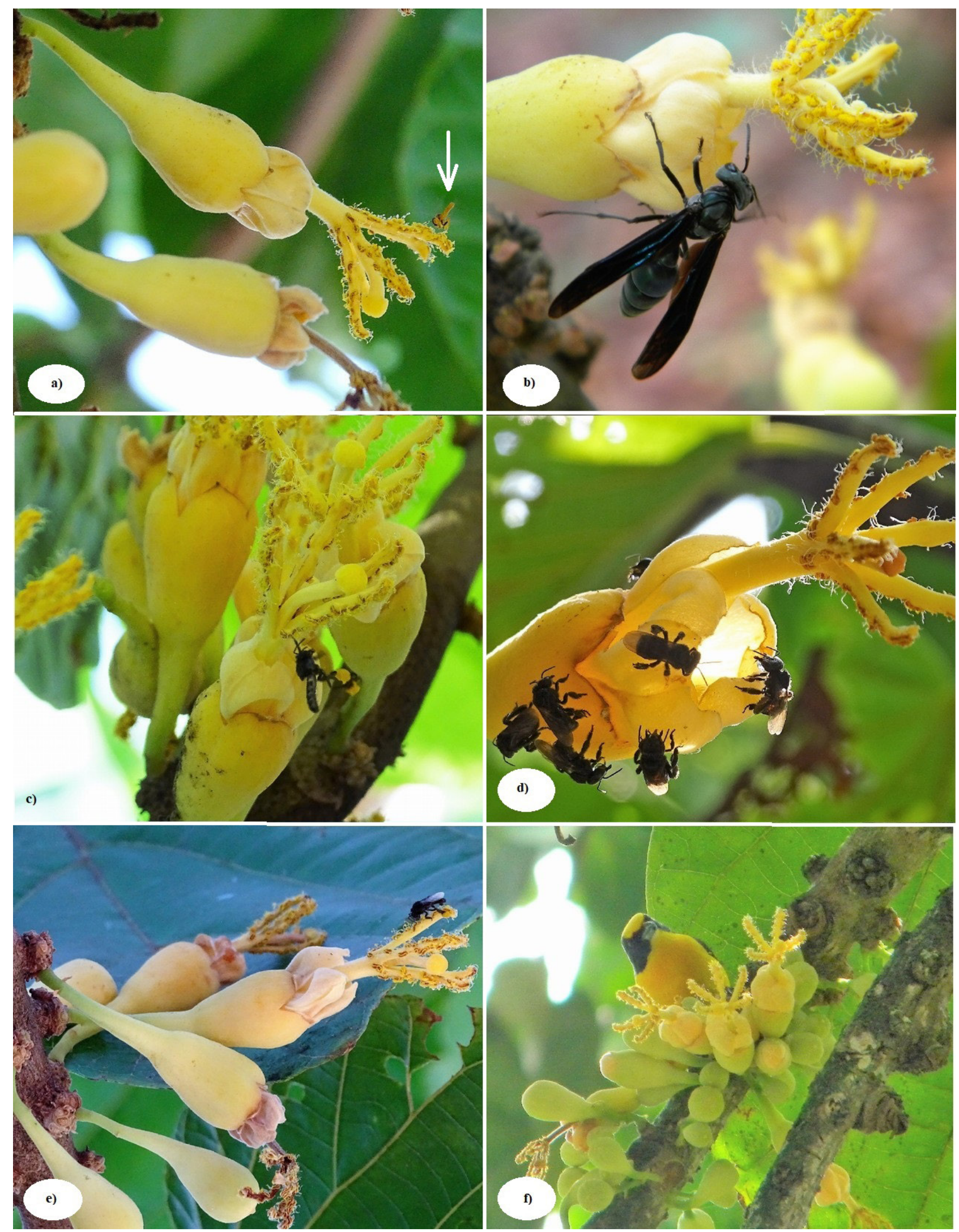

Figure 3. Some floral visitors of Matisia cordata from The Clavel farm (Sopetrán, Antioquia - Colombia). a) Tetragonisca angustula, b) Synoeca sp., c) Trigona fulviventris, d) Trigona amalthea, e) Trigona (frieseomelitta) nigra, f) Euphonia laniirostris. 


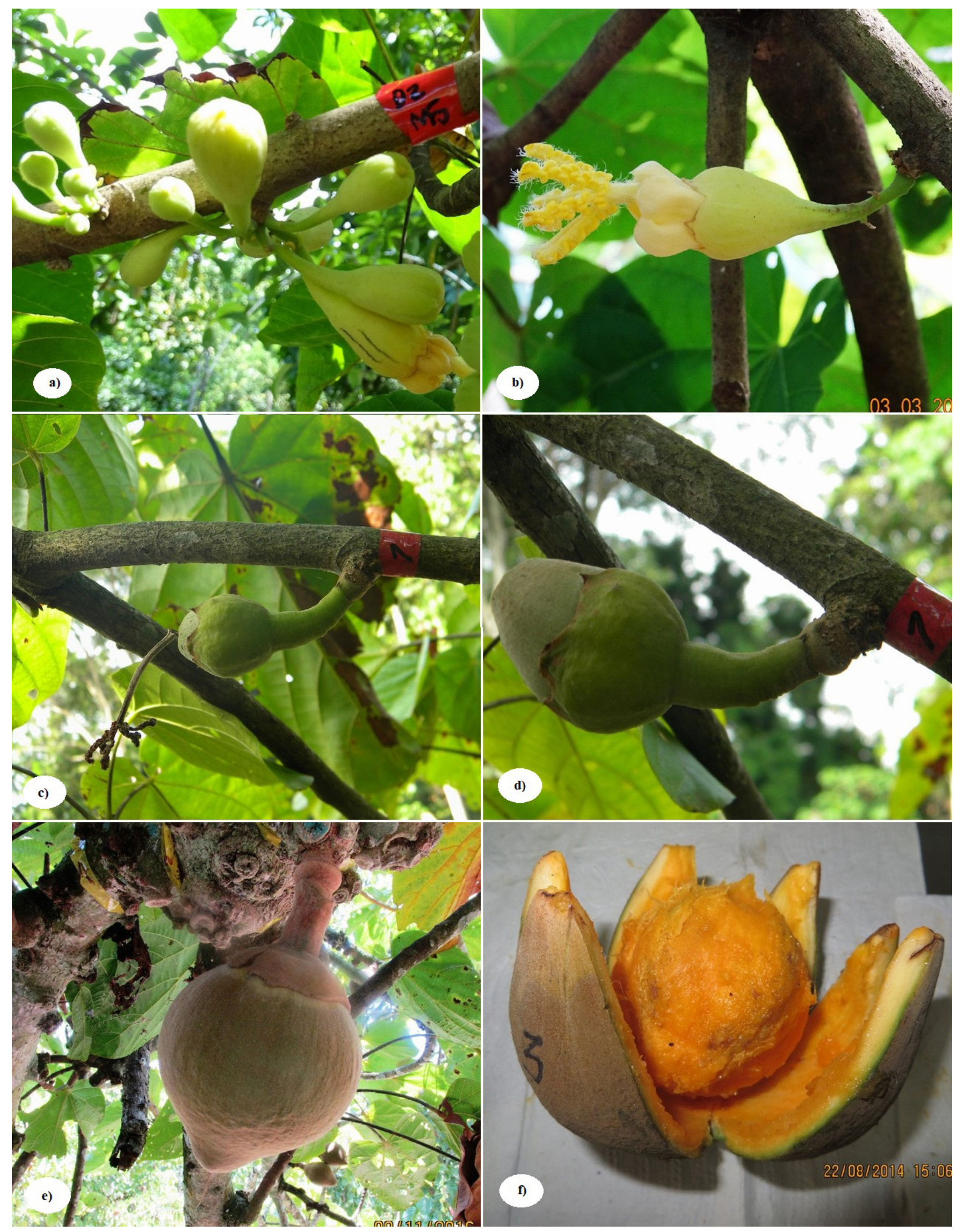

Figure 4. Stages of Matisia cordata flowering and fructification according to BBCH scale. a) flower buds - stage 4, b) flowers open - stage 5, c-d) development of fruit - stage 7, e-f) fruit at harvest maturity - stage 8 
The period from floral bud to matured fruit in sapoti crops is 269 days average, varying from 7 to 9 months. Only $2.7 \%$ of the floral buttons reached the matured fruit stage. Further studies on the productivity of this species are necessary to explain the low number of ripe fruits and its relationship with factors such as: the lack of soil fertilization in the region, and the existence of a physiological trade-off between the allocation of resources to abundant flowering and the cost of fruit formation (WEIH, 2003; BAJCZ and DRUMMOND, 2017). In the trees, the final number of fruits that reach the harvesting stage are a combination of the species genetic potential adjustment, flowering levels, inflorescence types, available nutrients and the tree capacity to take the nutrients to the growing fruits (REBOLLEDO and ROMERO, 2011). These factors can be conjugated with the priorities of local small producers, which not always are high production rates but the persistence of their life conditions (BARRERA, 2018). On the other hand, this study registered non-pollinator flower visitors that may be collecting more pollen than actual pollinators. This condition can also affect fruit formation.

Morphology of M. cordata flowers (with outward arranged stamens, 3-month flowering period and its high pollen and nectar production) suggests that the species is adapted to cross pollination mediated by animals. The allogamy is confirmed by the tendency to protandry, even though there is some overlapping in the maturity of pollen grains and the stigma in the 2-days old flowers, but the auto-pollination of $M$. cordata is also possible. The results of the pollen viability, the stigma receptivity and fruiting, support the hypothesis that sapoti invests in pollen dispersion in the first two days of flowering and after this age, it invest in female fitness to set fruits.

Sapoti flowers have various characteristics of different pollination syndromes: the pollen yellow color is related with daytime pollination insects (AMAYA, 2017); the permanent 3-5 days opened flowers, easily accessed, with abundant nectar and pollen allows daytime and nighttime visitors. These characteristics reflect a generalist or mixed pollination system, that favors a high-rate visits of many animals.

The possibility of adapting to changing conditions is one of the advantages of generalist pollination system (AVILA et al., 2015). In species such as sapoti, which has a limited flowering period per year, it is possible that the best strategy to assure fecundation is to attract as many pollinators as possible during the short flowering period. Although species with generalist pollination system can receive many visitors, only effective pollinators influence the formation of flower characteristics (FENSTER et al., 2004) and fruits. Hence, it is important to study the nature of effective pollinators and whether they act as a limited resource for the species.
The greatest nectar production was found in 2-days flowers during morning hours. This can be explained by the synchronization of two main facts: (1) the full maturity of the all reproductive structures, and (2) visits of morning pollinators such as insects, bees and birds that start their activities early in the morning (KAKUTANI et al., 1993, REYES et al., 2007). Some studies have suggested that regular nectar extraction stimuli its total production (GILL, 1988). Thus, further studies that explore night nectar production and the amount of nectar extracted by night pollinators should be carried out.

It was found that $M$. cordata flowers have similar nectar volumes to other Bombacoidea species from the region (between 0.5 and $1.5 \mathrm{ml} /$ flower) (SCOGIN, 1986). Aditionally, M. cordata flowers are moderately diluted (between 11 and $20 \%$ of sugars) (SCOGIN, 1986) which fulfill the visiting requirements of bees (PARRA et al., 2017), hummingbirds and mammals (SCOGIN, 1986). The diluted nectar can be easily sucked without a great energy expenditure. Nevertheless, and for the plant convenience, pollinators must visit other similar flowers to compensate their requirements. Determining the nectar composition is important since nectars with a high hexose and sucrose content have been associated with ornithophilia and entomophilia, respectively; bats, on the other hand, do not show a clear preference (DUPONT et al., 2004).

Floral visitors. Meliponini bees such as Trigona (frieseomelitta) nigra, T. fulviventris, Tetragonisca angustula and Nannotrigona sp., as well as the Amazilia tzacalt hummingbird were the daytime visitors seen foraging sexual whorls of sapoti flowers. Night visitors as Artibeus lituratus, Glossophaga sorcina, Sturnira $s p$. and Dermanura sp. bats had pollen load. Although $M$. cordata effective pollinators in the region could be among the species listed above, small bees can also reach stamens without touching the stigma. This is unlikely to happen with bats visits. 24-hour studies are important to stablish whether other species, such as moths and little mammals, visit the opened flowers as reported in other regions (JANSON et al., 1981; TSCHAPKA, 2004). Detailed experiments would allow to prove if the potential pollinators found in this study act as effective pollinators.

Trigona bees have been associated with flower damage and described as pollen and nectar robbers (RENNER, 1983; YOUNG, 1983; GUTIÉRREZ et al., 2018). Although T. amalthea was registered consuming petals of sapoti flowers, other species such as T. fulvientris and $T$. (fieseomeitta) nigra were observed on the flower reproductive structures (Figure 3b-d). According to previous studies, some of the nearly 75 species from Trigona genus (eof, 2018) are important pollinators (KAKUTANI et al., 1993; BEZERRA et al. 2020). 
Presence of Euglossinae bees might be influenced by artificial attractants, such as methyl salicylate and eucalyptol (SANTOS, 2009), used in harvesting activities in the sapoti crops. These attractants are focused on capturing males (PARRA et al., 2017). Surprisingly, a female individual was found at the crops with pollen on its body. Hence it is possible that Euglossinae bees visited flowers to obtain nectar, pollen and fragrances. Some studies have recorded both males and females of this species looking for resources in flowers of various botanic families (DRESSLER, 1985; RAMÍREZ et al., 2002).

A comparative study of the sapoti floral biology between individuals from the study region dry forest and individuals from natural forest would be interesting. It would allow to determine if there has been a differential selection pressure on its reproduction system.

Finally, in the last years the study region has gone through changes in the land use. This has affected sapoti trees since they are getting isolated from each other. Thus, determining how the changes in the land use affects the pollinators, pollination and sapoti fructification would be important for the study region.

\section{Conclusion}

This study documented floral biology aspects of $M$. cordata, that confirm that the crossed pollination mechanism prevails. Although the species assigns a lot of resources to flower production and floral rewards for visitors, only $2.7 \%$ of the floral buttons reached the matured fruit stage at the studied farms, between 7 and 9 months after flowering. Further studies that investigate the low fruit production at the region are necessary to improve the production rates of small producers. Sapoti has a generalist pollination system since it attracts bees, bats and birds from the Trochilidae family that participate in this process. The synchronized flowering adds abundant pollen and nectar that attracts many animals to feed, even insectivorous species. This demonstrates that sapoti flowers act as a great and abundant resource for animals in the region.

\section{Acknowledgments}

To the Politécnico Colombiano Jaime Isaza Cadavid and Colciencias (Convocatoria 706 de 2015 grant awarded to M. Aguilar) for funding. To J. Rivera and J. García-Ruiz, for allowing us to carry the research in their farms. To M. Barrera for the statistical analysis and to R. Correa the birds' identification. To V. RestrepoCossio and J. Uribe for helping during field work. To the Francisco Luis Gallego Entomology Museum of the Universidad Nacional de Colombia - Medellín, specially to G. Guarín and J. Quiroz for insect identification. To the Palynology Laboratory of the Universidad Nacional de Colombia - Medellín, specially to Y. Castañeda for pollen's quantification and identification. Finally, to the Mastozoology Research Group of the University of Antioquia for the field support and identification of the bats.

\section{References}

ALVAREZ-LOAYZA, P.; TERBORGH, J. Fates of seedling carpets in an Amazonian floodplain forest: intracohort competition or attack by enemies?. Journal of Ecology, London, v.99, p.1045-1054, 2011.

ÁlVAREZ, V.; MURIEL S.; OSORIO, N. Plantas asociadas al turismo y los sistemas tradicionales de manejo en el occidente cercano antioqueño. Revista Ambiente y Desarrollo, Bogotá, v.19, p.67-82, 2015.

ALVES-DOS-SANTOS, I.; DA SILVA, C.; PINHEIRO, M.; DE MATOS, P.; KLEINERT, A. Quando um visitante floral é um polinizador?. Rodriguésia, Rio de Janeiro, v.67, p.295-307, 2016.

AMAYA, M. Polinización y biodiversidad. In: NATES G. (ed.). Iniciativa colombiana de polinizadores abejas ICPA. Bogotá: Universidad Nacional de Colombia, 2017.

AVILA JR, R.; PINHEIRO, M.; SAZIMA, M. The generalist Inga subnuda subsp. luschnathiana (Fabaceae), p.negative effect of floral visitors on reproductive success? Plant Biology, New York, v.17, p.728-733, 2015.

BAJCZ, A.; DRUMMOND, F. Bearing fruit: flower removal reveals the trade-offs associated with high reproductive effort for lowbush blueberry. Oecologia, Berlin, v.185, p.13-26, 2017.

BARRERA, M.;MURIELS.;VÉLEZL. Multifuncionalidad de los en sistemas de producción tradicional del occidente cercano antioqueño como respuesta a la apropiación del territorio. In: CONGRESO INTERNACIONAL DE SISTEMAS AGROALIMENTARIOS LOCALIZADOS, 8.; Manizales, 2018. Anais [....]. Manizales: Universidad de Caldas, 2018.

BEZERRA, L.; CAMPBELL, A.; BRITO, T.; MENEZES, C.; MAUÉS, M. Pollen loads of flower visitors to açaí palm (Euterpe oleracea) and implications for management of pollination services. Neotropical Entomology, Londrina, v.49, p.482-490, 2020.

CERÓN, I.; NG, R.; EL-HALWAGI, M.; CARDONA, C. Process synthesis for antioxidant polyphenolic compounds production from Matisia cordata Bonpl.(zapote) pulp. Journal of Food Engineering, London, v.134, p.5-15, 2014. 
CHÍZMAR, C. Plantas comestibles de Centroamérica. Costa Rica: NBio Editorial, 2009.

DRESSLER, R. Euglossine bees (Hymenoptera, p.Apidae) of the Tambopata reserved zone, Madre de Dios, Perú. Revista Peruana de Entomologia, Lima, v.27, p.75-79, 1985.

DUPONT, Y.; HANSEN, D.; RASMUSSEN, J.; OLESEN, J. Evolutionary changes in nectar sugar composition associated with switches between bird and insect pollination. The Canarian bird-flower element revisited. Functional Ecology, Oxford, v.18, p.670-676, 2004.

EOL. Enciclopedia on life. Disponível em: https://eol. org/pages/2757318. Acesso em: 5 maio 2018.

ENZ, M.; DACHLER, C. Compendio para la identificación de los estadios fenológicos de especies mono y dicotiledóneas cultivadas escala BBCH extendida. Limburgerhof: Basf, 1998.

ERDTMAN, G. Pollen morphology and plant taxonomy: Angiosperms (an introduction to palynology I). New York: Hafner Publishing, 1966.

FENSTER, C.; ARMBRUSTER, W.; WILSON, P.; DUDASH, M.; THOMSON, J. Pollination syndromes and floral specialization. Annual Review of Ecology, Evolution and Systematic, Palo Alto, v.35, p.375-403, 2004.

FONNEGRA, R. Métodos de estudio palinológico. Medellín: Centro de Investigaciones de la Facultad de Ciencias Naturales y Exactas, Universidad de Antioquia, 1989.

GILL, F. Effects of nectar removal on nectar accumulation in flowers of Heliconia imbricata (Heliconiaceae). Biotropica, Washington, v.20, p.169-171, 1988.

GUTIÉRREZ, C.; PANTOJA, J.; KLEIN, A. Floral larceny by the stingless bee Trigona amalthea on granadilla (Passiflora ligularis Juss). Journal of Pollination Ecology, Toronto, v.22, p.75-81, 2018.

JANSON, C.; TERBORGH, J.; EMMONS, L. Non-flying mammals as pollinating agents in the Amazonian forest. Biotropica, Lawrence, v.13, p.1-6, 1981. Suplemento

JEANNE, R.; TAYLOR, B. Individual and social foraging in social wasps. In: JARAU, S.; HRNCIR, M. (ed.). Food exploitation by social insects. Ecological, Behavioral, and Theoretical approaches. Boca Raton: CCR Press Taylor and Francis Group, 2009.
KAKUTANI, T.; INQUE, T.; TEZUKA, T.; MAETA, Y. Pollination of strawberry by the stingless bee, Trigona Minangkabau, and the honey bee, Apis mellifera, p.experimental study of fertilization efficiency. Research on Population Ecology, Tokyo, v.35, p.95-111, 1993.

KISSER, J. Bemerkungen zum einschulss in glyceringelatine. Zeitschrift Für Wissenschaftliche Mikroskopi, Stuttgart, v.51, p.372-374, 1935.

LIM, T. Quararibea cordata. In: LIM, T.K. Edible medicinal and non-medicinal plants. Dordrecht: Springer, 2012. p.590-592.

MORTON J. Chupa-chupa. In: MORTON, J. Fruits of warm climates. Winterville: Creative Resources Systems, 1987.

NATES, G.; OSPINA, R.; RODRÍGUEZ, A.; CHAMORRO, F.; HENAO, M.; CALDERÓN, L.; PINILLA, S. Polinización en cultivos promisorios. In: NATES G. (ed.). Iniciativa colombiana de polinizadores capítulo abejas ICPA. Bogotá: Universidad Nacional de Colombia, 2017.

OSBORN, M.; KEVAN, P.; LANE, M. Pollination biology of Opuntia polyacantha and Opuntia phaeacantha (Cactaceae) in southern Colorado. Plant Systematics and Evolution, Wien, v.159, p.85-94, 1988.

PARRA, A.; OTERO, T.; SANDINO, J.; OSPINA, R. Abejas euglosinas (Hymenoptera: Apidae: Euglossini) y su importancia como polinizadoras de amplio rango en ecosistemas naturales. In: NATES, G. (ed.) Iniciativa colombiana de polinizadores capítulo abejas ICPA. Bogotá: Universidad Nacional de Colombia, 2017

PIZANO, C.; GARCIA, H. El bosque seco tropical en Colombia. Bogotá: Instituto de Investigación de Recursos Biológicos Alexander Von Humboldt, 2014.

PRAGLOWSKI, J. The effects of pre-treatment and the embedding media on the shape of pollen grains. Review of Palaeobotany and Palynology, New York, v.10, p.203-208, 1970.

R Development Core Team. R: language and environment for statistical computing. Vienna: The R Foundation for Statistical Computing, 2009. Disponível em: http:// www.R-project.org/. Acesso em: 5 maio 2018.

RAMÍREZ, S.; DRESSLE, R.; OSPINA, M. Abejas euglosinas (Hymenoptera, p.Apidae) de la Región Neotropical, p.Listado de especies con notas sobre su biología. Biota Colombiana, Bogotá, v.3, p.7-118, 2002. 
RAVERET-RICHTER, M. Social wasp (Hymenoptera, Vespidae) foraging behavior. Annual Review of Entomology, Palo Alto, v.45, p.121-150, 2000.

REBOLlEDO, A.; ROMERO, M. Avances en investigación sobre el comportamiento productivo del aguacate (Persea americana Mill.) bajo condiciones subtropicales. Ciencia y Tecnología Agropecuaria, Guatemala, v.12, p.113-120, 2011.

RENNER, S. The widespread occurrence of anther destruction by Trigona bees in Melastomataceae. Biotropica, Lawrence, v.15, p.251-256, 2003.

REYES, J.; EISCHEN, F.; CANO, P.; RODRIGUEZ, R.; NAVA, U. Pollen collection and honey bee forager distribution in cantaloupe. Acta Zoologica Mexicana, Xalapa, v.23, p.29-36, 2007.

ROGG, H. Manual manejo integrado de plagas en cultivos de la amazonia ecuatoriana. Quito: Mosaico, 2001.

ROJAS, S. Asociación entre el robo de néctar y las características florales en una comunidad montana de los Andes colombianos. Ecosistemas, Granada, v.22, p.107$112,2013$.

SANTOS, A. Contribución al conocimiento de las abejas Euglossini (Hymenoptera: Apidae) y la utilización de dos atrayentes químicos, en la Reserva Forestal La Tronosa, provincia de Los Santos, Panamá. In: ESCOBAR, C.G.; JIGYŌDAN, K.K. (col.). Evaluación de la biodiversidad en la reserva forestal la Tronosa, Provincia de los Santos. Panamá: Proyecto PROBIOUniversidad de Panamá, 2009.

SCOGIN, R. Reproductive Phytochemistry of Bombacaceae. Aliso, Claremont, v.11, p.377-385, 1986.
SHIVANNA, K.; TANDON, R. Reproductive ecology of flowering plants: a manual, New Delhi: Springer, 2014. p.107-123.

SECRETARÍA DE AGRICULTURA Y DESARROLLO RURAL (Colombia) - Anuario estadístico del Sector Agropecuario en el departamento de Antioquia. Colombia: Gobernación de Antioquia, 2014.

STANGROOM, J. Chi-Square test calculator. Social Science Statistics. 2021. Disponível em: https:// www.socscistatistics.com/tests/chisquare2/default2. aspx. Acesso em: 2 jan. 2021.

STRIEGEL, L.; WEBER, N.; DUMLER, C.; CHEBIB, S.; NETZEL, M.; SULTANBAWA, Y.; RYCHLIK, M. Promising tropical fruits high in folates. Foods, Basel, v.8, p.363, 2019.

TROPICOS. Missouri botanical garden. 2018. Disponivel em: http://www.tropicos.org. Acesso em: 21 fev. 2018.

TSCHAPKA, M. Energy density patterns of nectar resources permit coexistence within a guild of neotropical flower-visiting bats. Journal of Zoology, London, v.263, p.7-21, 2004.

WEIH, M. Trade-offs in plants and the prospects for breeding using modern biotechnology. The New Phytologist, Oxford, v.158, p.7-9, 2003.

YOUNG, A. Nectar and pollen robbing of Thunbergia grandiflora by Trigona bees in Costa Rica. Biotropica, Lawrence, v.15, p.78-80, 1983. 